\title{
Hope emplaced. What happens to hope after arrival: The case of Ecuadorian families living in Italy
}

\author{
Roberta Raffaetà \\ University of Milano-Bicocca, Department of Educational Human Sciences “Riccardo Massa”, Anthropological and Ethnological Sciences, Italy
}

\section{A R T I C L E I N F O}

\section{Article history:}

Received 31 August 2013

Received in revised form

2 March 2015

Accepted 6 April 2015

Available online 2 May 2015

\section{Keywords:}

Affects

Emotions

Hope

Space

Time

Agency

\begin{abstract}
A B S T R A C T
In the literature, hope has been mainly analyzed as an emotional state linked to temporality. This stance has prompted criticism of hope as projecting promises, which may never be fulfilled, into an indefinite future. Whilst this is partly true, this paper aims to enlarge previous approaches by illustrating hope's connection with spatiality. The paper examines 'hope' among Italian families of Ecuadorian origin, through analysis of affective states produced by the place to which they have migrated. Hope emerges as a dynamic relation between the resources one has and the place one is in. The spatial dimension of hope mitigates criticisms of its evanescence; the paper emphasizes the political aspects of hope as a resource for migrants to realize their agency and interact with the world.
\end{abstract}

(C) 2015 Elsevier Ltd. All rights reserved.

\section{Introduction}

The idea of a 'promised land' is a strong cultural trope (Fenton, 2006) which binds together hope (in the guise of 'promise') and space (the 'land') for the people traveling to find it. In the literature, however, hope has been mainly analyzed in its temporal dimension, as an emotional projection into the future. Considered in purely temporal terms, hope may appear as an illusory state, and therefore a potentially deceitful condition, which projects promises which may never be fulfilled into an indefinite future (see, for example Warren and Manderson, 2008). This argument certainly has some truth to it. However, the spatial dimension of hope has been neglected and this has obscured hope's important aspects. In this paper, I take a complementary approach which conceives hope as space and, in doing so, enrich time-related views on hope by showing its spatial characteristics. This paper analyses the everyday lives of women who have migrated with their husband and/or children from Ecuador to a north-eastern region of Italy. Some of the Ecuadorians who took part in my research, in recounting their lives, indicated that hope is materially distributed in significant spaces. Thus conceived, hope is not just a coping mechanism to be engaged while waiting for a better future. Rather, it also affects and

E-mail address: roberta.raffaeta@gmail.com. effects people's lives in the present. The spatial dimension of hope mitigates criticism of its evanescence. By identifying hope within spaces, these migrants found resources with which to accomplish their agency in the best and most creative manner possible, and which enabled them to interact with the host community in their own cipher.

Moreover, the study of hope within migration studies is usually focused in the expectations formed before migration, as part of the imaginative work at the base of the motivation to migrate. Not enough work is done to think about what happens to hope after migrants' arrival. By focusing on migrants' experiences after arrival and through settlement, the paper shows that the abstract and time-related aspects of hope become more concrete when they are elaborated in relation to the place of settlement. Unraveling the specific actions and practices which give meaning to hope yields understanding of its connection with space.

To discuss the spatial aspect of hope, I employ the conceptual framework offered by Duff (2011), who proposes a logic of 'enabling places' grounded in a comprehensive review of research on health and place. On examining the enabling dimensions of place, Duff (2011: 152-5) proposes three classes of enabling resources: social, material and affective. This paper is focused on the last class. Affective resources are the ways in which individuals and groups manipulate or modify their affective states through places: for example, in the ways that certain places help to generate or sustain 
discrete feeling states (Thrift, 2004: 59-64). The analysis of affective resources is intended to capture something of the resonant 'feeling' of place alluded to in discourses on hope. Space contributes to generate hope both through its physical and material experience, and through the social and relational aspects of these experiences (Thrift, 2004).

\section{Research setting and methods}

This study derives from ethnographic research conducted from 2011 to 2013 on the experiences of immigration and parenting among 17 Ecuadorian families living in Val Rendena, an Alpine valley in Trentino, a northern region of Italy. Most Ecuadorian migrants in Val Rendena originate from the Province of El Oro (in the south-west coastal region of Ecuador, close to the border with Peru). Financial instability in the late 1990s and early 2000s induced more than a million Ecuadorians (7\% of the national population) to emigrate, mostly to Italy, the USA and Spain (Boccagni, 2011: 1). In Italy, most Ecuadorians settled in Genoa, Milan, Rome, Perugia and Piacenza (ISTAT, 2011), with a significant number being established in Trentino, where they settled either in Trento, the most populous city in the region, or in Val Rendena. Trentino counts around 48,000 migrants, or $9.2 \%$ of the provincial population (Ambrosini et al., 2011). The total population in Val Rendena amounts to almost 10,000 people, of whom only 587 are migrants, with approximately 137 originating from Ecuador (almost one-quarter of the total number of migrants in the valley) (Servizio Statistica della Provincia Autonoma di Trento). Despite the substantial geographical isolation of Val Rendena, it is a destination for migrants because Trentino has a history of significant political and economic autonomy. Val Rendena, moreover, is a tourism region. These two factors jointly ensure relatively high living standards compared to elsewhere in Italy.

A series of strategies were employed to ensure diversity in the recruitment of families across the region, and occurred through local family health and social services, Val Rendena's multicultural association, and personal networks. Initial participant contact was complemented by snowball recruitment as primary research participants gave further contacts through their families and social networks. The interviewees were chosen by means of theoretical sampling (Becker, 1998). The research participants selected had to be currently living in Val Rendena, to have been born in Ecuador, and to have one or more children aged 6 years or younger. Consistent with these criteria, participants were aged between 22 and 42 years, with a mean age of 25 . Of the 17 families recruited for the study, 15 were 'closed' in that all members were Ecuadorian; one family was mixed, with an Ecuadorian woman married to a local Italian man; and there was one single parent (mother) family. Observations encompassed activities and places in which both parents were present. In contrast, interviews were mainly carried out with women because I established more intimate contact with them; they also felt more comfortable than men in discussing their parenting experience with a female researcher.

A three-stage methodology was devised to analyze participants experiences of migration. It involved in-depth interviews, in situ participant observation, and photo-elicitation according to the "photo-voice" method (Wang and Burris, 1997). Interviews were conducted in Italian and/or Spanish, as the interviewee preferred. A full participant information and consent protocol was administered prior to the commencement of all research activities.

Early contact with Ecuadorian community members, especially women, created opportunities for more extensive participant observation. Accompanied by my pre-school age daughter, I often met local Ecuadorian mothers and their children at local playgrounds or in their homes. Following these initial encounters, I was invited to attend weekend community gatherings, various parties, and community celebrations. I also attended public meetings organized by a multicultural association operating in Val Rendena and undertook volunteer work as an Italian language teacher for an association offering Italian language classes to newly-arrived migrants.

Issues of affect, space and place emerged as key themes throughout the interviews and observational research. The use of photo-voice to document local places enabled me to understand the links among place, community and belonging more deeply. The use of photo-voice was stimulated by recent calls for more innovative methods to trace the interplay among the environmental, social and symbolic dimensions of place and place-making (Conradson, 2005; Cummins et al., 2007; Fogel et al., 2008; Macintyre et al., 2002). Visual methods such as photo-voice are particularly suited to understanding people's experiences of place, with emerging evidence suggesting that they are especially well suited to tracing the embodied, material and affective dimensions of place and belonging (Pink, 2006; Tolia-Kelly, 2007). Consistent with the photo-voice method, I asked participants to take photographs of local places that they particularly liked and/or felt attached to. Of the 17 families interviewed for the study, 10 elected to participate in this component of the research. Each was offered a disposable camera, although eight decided to use their own camera.

Interviews, photographs and fieldnotes were analyzed thematically, with analytic categories emerging to inform the development of further coding variables. All quotations reported below were translated from Italian/Spanish into English.

\section{Destination hope}

I began my inquiry into the Ecuadorians' understanding of their migratory paths as part of a research project on parenting and migration, and was particularly interested in understanding how being a parent interacts with migration. I had no pre-conceived idea about, or interest in, hope or space, but these issues strongly emerged during the research process and I adapted my research focus and methodology accordingly. This included employing photo-voice methodology to go deeper in eliciting Ecuadorians' meaning of place.

For most of the people interviewed, hope prompted their decision to leave Ecuador in search of a better life. Quite conventionally, the people I met explained to me how their decision to leave was sustained by the hope for a better future given the precariousness of Ecuadorian daily life. This kind of hope is an imaginative work, fully projected into time, and was based on stories of other migrants, relatives and friends who did succeed abroad. These narratives helped them to imagine their future abroad and that of their children, while developing a hopeful attitude. The research focus on parenting practices accidentally contributed to elicit reflections on the temporal aspect of the migratory experience. Often, the decision to migrate was motivated by the fact of assuring a better future for the migrants' children. Parents decided to bear the hardship of a migration because they imaginatively projected their lives into the future path of their children.

After arrival in Italy, hope remained linked to time in various ways. First, people continued to imagine and work for a prosperous future. Second, some hoped to return to Ecuador at an indefinite point in the future, perhaps when they reached retirement age. Toward the end of my fieldwork, this hope was evoked more often, as Italy's economy and political prestige declined and Ecuador was re-structuring its welfare and bureaucratic system. 


\subsection{Hope and space}

After arrival and through settlement, a different kind of hope complemented the time-related view of hope, and stressed the space-related aspects of hope. Victoria, 33, arrived in Val Rendena in 2001 to work and later married a local Italian man with whom she had a two-year-old child. She explained:

"When we arrived here, we all had a fixed idea: to make some money and stay here two to three years. But you see, the years went by and we're still here [she laughs]. Here everything is quiet and clean. In Ecuador, there's a lot of crime, it is not a safe place, especially for children. I think that I would have liked to remain here even if I hadn't married an Italian man."

Victoria stressed her attachment to the 'quiet' and 'clean' place where she now lived through the entire interview. She had left Ecuador with the hope of making some money and returning home soon afterwards. Having settled in Val Rendena, she decided to stay because the material aspects of the place of settlement made her past dreams for a better life real, even is somehow different. The hope in making money transformed into the experience of having a good life by living in a safe place. This experience also continuously reinforces Victoria's hope for a better future, making it more concrete as it was bound to a specific space.

How space was connected in a crucial way to the hopes that sustain people's migratory experience became apparent during a meeting hosted for new immigrants by local political authorities in Val Rendena (for more details see Raffaetà and Duff, 2013). While other migrant groups asked for better employment and housing opportunities, the Ecuadorian migrants lamented the lack of free access to public places in the village to gather together as a community to chat, gossip, and play team sports. In previous years, Ecuadorians had met in the village pinewood. At a certain point, however, the mayor forbade them to gather there because there were too many people and their presence disturbed tourists; instead they were directed to a large space, outside of the village. At the meeting, the Ecuadorians' request to have more space was somehow misunderstood by the president of the Valley Community. She recounted how Val Rendena is a world-wide well appreciated tourist destination for its high mountains and wilderness: Ecuadorians could easily find green areas to gather. But the Ecuadorian community was not asking for breath-taking landscapes of untouched wilderness but, to the contrary, to be recognized as citizens entitled to take advantage of the community public spaces. This recognition stayed as a lively and concrete confirmation that their migration had reached some tangible results.

How hope springs from places, and how this hope unfolds and sustains agency, emerged strikingly from Rosa's story and photographs. Rosa, 24, came to Italy in 2008 to join her husband who had arrived in Italy one year earlier. She was pregnant at the time of our first interview and spent much of her time caring for Mathias, her three-year-old son. She told me that it had initially been hard for her to live in Italy, even though it was a temporary choice. Soon afterwards, however, she had begun to appreciate the place where she lived and, during the interview, expressed her desire to stay permanently, no longer wanting to return to Ecuador. Similar to Victoria, she was convinced that Italy - Val Rendena especially was a better place for her children to live because it was clean, safe and peaceful.

In a subsequent meeting, she showed me the photographs that she had taken for the photo-voice component. These portrayed the order of civic life in the village. One was especially distinctive in that it depicted a part of the village dedicated to the local system of separate refuse collection. In discussing this photo, Rosa indicated how she and her family could enjoy the higher hygienic and safety standards of Italy compared to Ecuador. More than this, her picture addressed the issue of how people, including migrants, become attached to a place through daily practices. The separate refuse collection area was composed by a number of boxes with a colored lid. Every color indicated a specific type of litter: green for glass, yellow for plastic and aluminum, white for paper, black for norecyclable, and brown for organic. The wide circular boxes were covered with wood, a feature which helped them to integrate with the Alpine-style of the village houses. The area was cleaned twice a day and remained under camera surveillance. The village, and the entire Trentino Province, has endorsed this kind of refuse collection for more than a decade; this is supplemented by the production and dissemination of informative material to show people how to separate garbage and to educate them on the ecological, economic and moral value of this operation. The issue goes far beyond hygienic standards: it acts as a very important measure of civic sense and how people come to belong to a place through their continual, even minimal, efforts to care for the place they inhabit. Rosa explained to me that, in Ecuador, there is not a well-organized system to throw away refuse. Streets are punctuated by various refuse disposal systems and there are certain parts of the city where the garbage is amassed, open-air, producing "noxious fumes harmful for health". In Ecuador, garbage collection appears foremost as a health issue, even before being recognized as a social one. Given this, for Rosa, the refuse collection area in Val Rendena came to represent a form of recognition of her presence and her future opportunities through taking part in caring for the common place. The places pictured with photo-voice methodology thus took their importance not from abstract spatial dimensions, but because they showed loci where activities were performed, where stories could be traced, and where various human and non-human elements had been assembled. The boxes of garbage depicted by Rosa were neither places nor sources of hope in themselves. Out of context, they might be regarded as simple objects. However, things do not so much exist as they occur in their enactment of trajectories which are performed in specific contexts. Space is not an empty shell, so the difference between objects and places is only illusory because places are made of things and of open-ended relations.

Other photographs taken by Rosa depicted mountains. As our friendship developed, she asked me to take her and Mathias up into the mountains because her husband never had, despite her strong desire. She also asked me if I could teach Mathias to ski. During our days together in the mountains, she confessed to me that she was very worried because, given her pregnancy, she was unable to work and contribute to the family income. Therefore, her husband Alejandro was thinking of sending her and Mathias back to Ecuador where life was cheaper; he would then join them later. During the following months, she was able to persuade her husband to let them stay in Italy. To achieve this goal, she did little jobs during her pregnancy and when her second son arrived (March 2011), she started to work a few weeks after his birth, struggling to take care of both the children and the house. In the meantime, Alejandro decided that the entire family should return to Ecuador because he wanted his children to grow up with Ecuadorian values. He wanted to be back in Ecuador before Mathias began his first year of school: "otherwise we'll be trapped here, once Mathias has started school". Despite Rosa's constant gentle efforts to persuade Alejandro to stay, during the summer of 2012 he told her that he had decided to leave before April 2013: "I am the man, and I decide where my family lives!". However, he had not yet decided on a date to leave, nor had he spoken about this decision to his employer or bought the airline tickets. Nevertheless, in January 2013, Alejandro ordered Rosa to do the packing, leaving their small apartment full of baggage. This was very awkward, especially when Rosa needed something from one 
of the suitcases. A firm decision about departure, however, was still pending. Rosa, with glistening eyes, consoled herself by thinking that at least she had been able to persuade Alejandro to live in the Sierra, where they could enjoy an environment similar to that in Val Rendena: "I don't want to leave, but there are mountains there as well, the climate is cooler, and it is safe and peaceful, so it's better than nothing." On a cold morning in February 2013, Mathias was transported by emergency helicopter to Trento hospital because he had suddenly lost consciousness. The family later discovered that Mathias might suffer from epilepsy. This convinced Alejandro to relinquish his desire to return to Ecuador and to remain in Italy, where Mathias could receive better medical care. Despite her concern about her son's health, Rosa was very happy to remain in Italy. At the time of writing this paper, I was helping Rosa to unpack bags in the evening while our children played noisily.

Rosa's hopes and struggles to stay in Italy arose from her experience of the specific places to which she had migrated. Mountains, but also ordinary places, like the local system of separate refuse collection, became much-valued triggers of hope. Val Rendena certainly comprises specific organizational configurations (ecological awareness, valorization of civic order, well-coordinated institutions) which structure it in a specific way. The social nature of space has been stressed in the scholarly debate (Corsin Jiménez, 2003; Leach, 2006; Rodman, 1992). Less emphasized has been the role performed by space itself in constituting social relationships and making them meaningful in specific ways. The very multiplicity of trajectories requires space; space establishes the possibility for different stories and elements (human and non-human) to run alongside one another (Massey, 2005: 95-9). Rosa performed her belonging to the host community through emplaced practices, such as the use of the system of separate refuse collection, her walks in the mountains, and her child's learning to enjoy the alpine environment (like locals) through learning to ski. At the same time, places are not just containers of the social; they are also facilitators and producers of it: Rosa, for example, identified certain characteristics (quietness, safeness, climate) in the mountain environment which she planned to translate to the Ecuadorian landscape in the Sierra.

\section{Hope as affect}

The majority of the women mentioned their hope of staying in Italy, which was expressed through the description of specific places or their characteristics. Their photographs revealed something of how this hope unfolded and was put into practice. The cleanliness of public spaces in Val Rendena was portrayed in many photographs as a measure of safety and civic order: a resource that promoted safe and healthy living. Maria, a single mother of two who had arrived in Italy in 2001, showed me a photograph of a playground:

"Here there are playgrounds as well: this is a good thing. There [in Ecuador] there are some playgrounds but they're scruffy. People don't take care of them, they destroy them, they even steal the flowers. They don't take care of these things; this [taking care of things] is something good that we are learning from living here. Children don't touch the flowers: this is a positive thing. We have to inculcate these things, for example, if

\footnotetext{
${ }^{1}$ Maria's words sound like an acritical appraisal of hegemonic values which seemingly devalorizes her original background. Her stance was rather more ambiguous and complex than this, however, because it often shifted to feelings of pride at being Ecuadorian and resistance to Italian values. A note was necessary here, despite this not being the focus of the paper.
}

you eat something you shouldn't throw the paper on the ground. Here we have learned how to live."

For these migrants, simple things like playgrounds and flowers were translated into the adoption of new practices and ways of thinking. ${ }^{1}$ In this process, flowers and playgrounds were not simple matters of fact: social practices like civic awareness and respect for nature and beauty are embedded in these places, intended as nodes where material, social and cultural elements are entangled. They created hope for Maria that her child would grow up with civic values. This hope, however, was not just in Maria's mind. It was emplaced: the playground was an ever-present and concrete resource helping Maria not to lapse into solipsism when she had to manage the complex interweaving among hopes, frustrations and anxieties as she encountered hardships along her migratory path.

The narratives, practices and pictures collected during the research made me think that the hope evoked after arrival and during settlement configures itself more as an affect than an emotion. Emotions and affects are distinct but overlapping concepts. Deleuze (1988 [1970]), in his reading of Spinoza, defined affect as a bodily state which interacts with the cultural construction of meanings. Affect is a state of being - or more properly becoming - and it is an emergent property of encounters between bodies, which can be human and non-human (Massumi, 2002). Yet bodies should not be defined by "an outer skin-envelope or other surface boundary but by their potential to reciprocate or coparticipate in the passages of affect" (Seigworth and Gregg, 2010: 2 ) because affective encounters imply immersion within a specific flux of the sensible. Affect creates resonant affinities between the body and the world, thus establishing a means for bodies and worlds to 'territorialize' one another (Grossberg, 2010). Affect is not merely a 'feeling': it is an embodied state which helps people orient themselves in relation to the world and thus to take action, thereby giving purpose, direction and sense to their existence. An emotion is, in comparison, a manifestation or interpretation of affect: is the moment when we make sense of a state of being/becoming (Hemmings, 2005: 551). Affect makes it possible to overcome an individualistic and disembodied understanding of internal states by emphasizing the relational character of our being-in-the-world. A turn to affect "refuses to treat, for example, experiences of happiness or misery as if they were a merely subjective matter that has nothing to do with a real world; and it refuses to consider the real world as a meaningless and objective matter that has nothing to do with the experiences and desires of subjects" (Greco and Stenner, 2013: 56). The people who contributed to my research were hopeful, so expressed an emotion. The exploration of how this hope came into practice, however, highlighted the affective character of hope: the result of a dynamic relation between the resources one has and the place where one is.

The specificity of places and their capacity to enter into a dynamic relationship with people was evident in Adriana's photograph of the local bank. Adriana had arrived in Val Rendena ten years previously with her child. She explained to me that working in a bank had always been her dream. Even though she had a university degree in accounting (obtained in Ecuador), she had given up the idea of working in the bank portrayed in the photograph because jobs rarely became available. Positions were held for a long time by the same people, and when there was a vacancy, it was more likely to be taken by a local person. Despite the inherent injustice of this situation, Adriana expressed these thoughts with a serene voice and attitude, while looking down at the table on which the photograph lay. There were two banks in the village where Adriana lived: one was a branch of a national bank (Banca Intesa); the other, depicted in Adriana's photograph, was a regional bank 
(Cassa Rurale del Trentino) with a strong social grounding and tradition in the village community. The former bank was located on the outskirts of the village, while the Cassa Rurale was in its centre. Adriana again looked at the photograph in silence, and then raised her face and stared directly at me, opening her eyes wide and smiling. She told me that her child would have a chance of accessing that job because "he was born here, he will grow up here, he will make friends here, and so he will have a chance to work in that bank". For Adriana, her abstract desire to work in a bank had the potential to become real and concrete in that specific bank, located right in the middle of the village but also at the core of local affairs. The existence of the Cassa Rurale, and its location in the village, which underscored and included distinctive social relations, generated hope. Adriana felt more in control of her migratory path and gave a meaning to it.

Places like schools, playgrounds, refuse collection sites, and banks grounded the opportunity for next generation Ecuadorian migrants to adopt Italian living standards and achieve what their parents could not. Banks and schools were sources of hope which revealed the crucial role of place and place-making in sustaining and producing hope. These places were not merely containers of social relationships, symbols of institutional regimes or lifestyles. Contrary to a radical social constructionist reading, these places were both a container and a producer of social dimensions because, in the dynamic entanglement of human and non-human actors, landscapes of sociality and power emerged (Jones et al., 2004). Hope was grasped in the very places where the research participants had settled. Hope for the future was rendered present in places, and had positive and instantaneous effects on migrants' social relationships and the management of their emotions.

Places also clearly had a significant impact on everyday life in Val Rendena for the research participants as formal constituents of their hopes. Hope was rendered real and present in specific places. The clean streets, tidy gardens, banks, and parks all fueled hope while, at the same time, they reassured the Ecuadorians about their decision to migrate and settle in Italy, thus slowly generating a sense of belonging. Ghassan Hage (2003) has already discussed how hope is spatially unequally distributed and Amanda Wise (2005) has shown how hope and belonging can be linked through space. In my research, migrants and places entered into a dialogue which made the advantages of migration visible and offered concrete grips which gave comfort in moments of fragility, calming the fears and anxieties which are part of the migratory process.

\section{Time, space and hope}

What do the Ecuadorians' stories and photographs tell us about hope? Wishing, tending toward something is, according to Spinoza (1677), the very essence of human and non-human nature. Heidegger (1993 [1927]) similarly identified the being-in-theworld of a person as a being 'towards something', striving for a feeling of direction, purpose, and sense. Hope, in other words, embodies the most fundamental experience of our existence. The paper shows that there are different kinds of hope and the need to extend the current discussion on hope to include the spatial dimension. Discussions on hope usually underline that temporality matters. Hope is always a belief in something which has "not yet become" (Anderson, 2006: 733). Hope has been illustrated as a trustful attitude about the future (Graw and Schielke, 2012), as an expectation that the future will somehow improve upon the present. This attitude was enacted by research participants while yet in Ecuador and imagining the future opportunities available in Italy. They prefigured that their quality of life and safety would improve. Their hopeful planning of the future crucially included the life of their children, with access to good education and to a successful career. This way of being hopeful has "chronopoietic" properties, in the sense that is able create time by extending the present into a projected future "replacing the closed temporality of doubt, uncertainty and affliction with a new divinatory temporality (Graw, 2014)".

To think of hope as simply time-related, however, creates some ethical problems. Proceeding from a temporal understanding of hope, many scholars have questioned its value. Anna Potamianou (1997) has argued that hope may maintain an attachment to something that is not attainable, or which has already been lost. In many cases, she argues, hope is merely hoping in hope. Sara Ahmed passes a similar critical judgment. ${ }^{2}$ She contends that happiness is a misleading emotion because, in order to be experienced, it has to direct one's attention to something beyond it. Happiness risks being a never-ending striving for something inherently unattainable: "If objects provide a means to make us happy, then in directing ourselves toward this or that object we are aiming somewhere else: toward a happiness that we are presumed to follow" (2010: 34). There is, indeed, a poisonous flourishing of discourses and practices based on 'positive psychology' developed in order to control and appease a growing number of "neurotic citizens" (Isin, 2004) rendered sick by "the misery, neuroticism, pessimism and general disenchantment generated en masse by the globalized market forces associated with neoliberalism." (Greco and Stenner, 2013: 56). In a similar vein, Lauren Berlant in her outstanding critique of optimism says that "A relation of cruel optimism exists when something you desire is actually an obstacle to your flourishing" (2011: 1). She argues that amid the turmoil of life, the optimism's projection into the future may feel like dread, anxiety, desperation, frustration, fear, neglect. Despite these malignant mutations, optimism is difficult to eradicate because it creates an enduring attachment to the desired object, beyond rational calculation.

All of these critiques have value and some truth. In my research, many Ecuadorians told me how their situation in Italy was a paler image of what they hoped for before they left Ecuador. In many cases, the overall evaluation of their migratory path was still satisfactory, but certainly not as glorious as imagined. Some of them felt stuck in Italy while life in Ecuador appeared to flowing in a more positive direction. Others confessed me that it would be better to return right now to Ecuador while the economy is still taking off, when all is still to be built and made. The fear to find oneself trapped in Italy was real in certain cases, as for Rosa's husband, who wished to return to Ecuador before his older child started school and so 'eradicate' himself and the family into a foreign land. Alejandro was afraid that the initial hope that sustained their travel to Italy, if not attentively monitored, would have created a risky yet enduring attachment to something not totally satisfying.

An analysis of hope restricted to its temporal dimension does indeed support these interpretations. But, as illustrated above, hope is not just time; it also involves space. Research participants' photographs showed that hope is not just a mental and solitary wandering along a timeline; it is materially distributed in space through practical engagement: going to school, throwing out garbage, walking in the mountains, skiing, etc. Among the Ecuadorian women covered by my research, hope was not just chronopoietic; it was geopoietic as well, in the sense that the women created meaningful experiences of place. Affects, contrary to emotions, are not just things that people carry around in their heads; rather, they have a relational, embodied and emplaced nature.

\footnotetext{
${ }^{2}$ She does not directly reflect on hope, but on happiness, which in her terms closely resembles the concept of hope.
} 
The intimate link between hope and space is mostly unintuitive. This has to do with the fact that the common idea of space inherited from classic philosophy is an impoverished one (see Massey's critique (2005: 22) of the Zeno's paradox). As famously stated by Foucault: "Space was treated as the dead, the fixed, the undialectical, the immobile. Time, on the contrary, was richness, fecundity, life, dialectic" (Foucault, 1980: 70). As a consequence, space's potential for politics was suppressed. To counterbalance this partial understanding, a number of geography scholars (Amin, 2004; Desforges et al., 2005; Jones, 2004; Massey, 1991, 1994, 1996, 2005) have shown that opportunities for political action and change lie not just in time, but also - and crucially - in space. This is exactly what the research participants showed to me: for them space was an important dimension of their hopes. So hope was not just something to be postponed but an affect to be lived in the present. Hope was initially evoked as linked to places, and their photographs helped to elaborate this unexpected insight. The Ecuadorian women in my research explained their hopefulness through a spatial mapping which directed their attention - and mine $^{3}-$ to specific places. Hope does not only reside in the future; it is also distributed in the present through acts and places. It strives for the future, but can also be depicted as a frozen state in the flux of becoming which has immediate effects.

\section{Conclusion}

Although the 'myth of return' (Anwar, 1979) was emotionally present, many of the Ecuadorian women to whom I spoke had decided to stay permanently in Val Rendena. They perceived that place furnished resources for them to feel well and to continue to be hopeful; through this affect, they gave meaning to their lives. As such, hope is not a purely psychological response; rather, it is grounded on specific places through particular ways of inhabiting them. The affective resources found in the spatiality of Val Rendena enabled the Ecuadorians to hope, and to renew their hope. Through the spatial distribution of hope in the place of settlement, hope was created and maintained. This generated positive present effects, even when the fulfillment of future dreams might be seriously threatened. The effects caused by affects as hope have a political meaning because they fuel attempts at social renewal.

Some scholars (Ahmed, 2008; Hemmings, 2005; Naisargi, 2006) have argued that affects are not universal, but are distributed or experienced unevenly in terms of relations of power. They may be the subject, or the affects, of others - for example, in relation to racism and sexism - but their affective experience is markedly different. People subject to hegemonic powers (like Ecuadorians in Italy) may lack the capacity to affect and to be affected because their agency is trapped by treacherous "power geometries" (ToliaKelly, 2006: 213). In other words, these criticisms downstate the emancipatory potential of affects as hope, and neglect their positive effects on minorities' life trajectories.

Notwithstanding the existence of power imbalances in migrants' lives, the stories presented in this paper highlight that hope has concrete and perceived effects, and these become apparent if we take spatiality into account. From this perspective, criticisms which focus solely on the macro pole of historical and political processes are less convincing: small improvements in life conditions perceived by the participants in the research - also provoked by their practicing of specific places - were very valuable for them. Through their photographs and discourses, they expressed a desire

\footnotetext{
${ }^{3}$ The Photo-voice methodology, thus, did not produce the results, as might be at first questioned. Rather, it was a tool with generative capacities to better understand insights that already emerged.
}

to be attached to life because "even those whom you would think of as defeated are living beings figuring out how to stay attached to life from within it, and to protect what optimism they have for that, at least" (Berlant, 2011: 10).

In their hoping, the Ecuadorians did not withdraw from life by dreaming of an unattainable future. Instead, they actively engaged with life through desire and wishes. They engaged in challenging negotiations in order to participate in world-making. The hope perceived by the Ecuadorian interviewees provided them with a fulfilling sense of being. The Italian anthropologist Ernesto de Martino (1948) defined the 'crisis of the presence' (crisi della presenza) as a disruptive experience provoked by diverse conditions (such as death, illness, moral conflicts, migration) in which a person or a group experiences profound uncertainty as to whether they can be part of a specific place and, therefore, of human history. Events of this kind engender a radical crisis in a person or people's historical being (as derived from the Heideggerian Dasein, which in its literal formulation equally stresses the emplaced nature of being). Against this risk, the stories illustrated above showed that the migrants strove to attain their historical being, their Dasein (herebeing) through hope. Their hope was not just a feeling; rather, it was a performative space that permitted and sustained a shift from passivity and suffering at being marginalized to an active search for meaning and settledness. The Ecuadorians' efforts to stay afloat with a comforting sense of hope should be analyzed in their own terms as political acts. Denying agency to people's modest attempts to act is to deny how minorities - migrants, in this case powerfully rewrite global-north sociopolitical as well as economic realities.

To conclude, hope as affect springs from its grounding in specific places and practices that compels us to substitute moral concerns with ethical ones (Braidotti, 2002). Framing hope within a predefined moral order (necessarily bad versus necessarily good) drains life from experience, and especially from its spatial contextualization. Ahmed has declared that "politics without hope is impossible, and hope without politics is a reification of possibility (and becomes merely religious)" (2004: 184). I agree, maintaining that hope is a political act in itself (Zournazi, 2002). To hope, and to write about other people's hoping - especially if these others are from non-mainstream groups - is an ethical and political responsibility.

\section{Acknowledgments}

This research has been possible thanks to a Marie Curie Fellowship COFUND Reintegration 2009. The approach exposed in the paper has been nourished along the years by the engaging exchange of ideas with my colleague and friend Cameron Duff, who I thank deeply.

\section{References}

Ahmed, S., 2004. The Cultural Politics of Emotion. Edinburgh University Press, Edinburgh.

Ahmed, S., 2008. The politics of good feeling. ACRAWSA E-journal 4.

Ahmed, S., 2010. Happy objects. In: Gregg, M., Seigworth, G.J. (Eds.), The Affect Theory Reader. Duke University Press, Durham, London.

Ambrosini, M., Boccagni, P., Piovesan, S., 2011. L'immigrazione in Trentino. Rapporto annuale 2011. CINFORMI, Trento.

Amin, A., 2004. Regions unbound: Towards a new politics of place. Geogr. Ann. 86B, 33-44.

Anderson, B., 2006. Becoming and being hopeful: Towards a theory of affect. Environ. Plan. D Soc. Space 24, 733-752.

Anwar, M., 1979. The Myth of Return: Pakistanis in Britain. Heinemann, London.

Becker, H.S., 1998. Tricks of the Trade. How to Think about Your Research while You're Doing it. The University Chicago Press, Chicago.

Berlant, L., 2011. Cruel Optimism. Duke University Press, Durham.

Braidotti, R., 2002. Metamorphoses: Toward a Materialist Theory of Becoming, Polity Press, Cambridge. 
Boccagni, P., 2011. Migrants' social protection as a transnational process: public policies and emigrant initiative in the case of Ecuador. Int J Soc Welf 20, $318-325$.

Conradson, D., 2005. Landscape, care and the relational self: Therapeutic encounters in rural England. Health \& Place 11, 337-348.

Corsin Jiménez, A., 2003. On space as capacity. J. R. Anthropol. Inst. 9, 137-153.

Cummins, S., Curtis, S., Diez-Roux, A., MacIntyre, S., 2007. Understanding and representing place in health research: A relational approach. Soc. Sci. Med.65, 1825-1838.

de Martino, E., 1948 [1970]. Il mondo magico. Universale Scientifica Boringhieri, Torino.

Deleuze, G., 1988. Spinoza: Practical Philosophy. City Lights Book, San Francisco.

Desforges, L., Jones, R., Woods, M., 2005. New geographies of citizenship. Citizsh. Stud. 9, 439-451.

Duff, C., 2011. Networks, resources and agencies: On the character and production of enabling places. Health Place 17, 149-156.

Fenton, M.C., 2006. Milton's Places of Hope. Spiritual and Political Connections of Hope with Land. Ashgate, Aldershot.

Fogel, A., King, B., Shanker, S., 2008. Human Development in the Twenty-first Century: Visionary Ideas from Systems Scientists. Cambridge University Press, Cambridge.

Foucault, M., 1980. Questions on geography. In: Gordon, C. (Ed.), Power/Knowledge: Selected Interviews and Other Writings, 1972-1977. Harvester Wheatsheaf, London.

Graw, K., 2014. Divination in Times of Migration: Globalization, Subjectivity, and the Path of Travel in Senegal and Gambia. Paper presented at United Nations University Institute on Globalization. Culture and Mobility (UNU-GCM), Barcelona.

Graw, K., Schielke, S., 2012. The Global Horizon. Expectations of Migration in Africa and the Middle East. Leuven University Press, Leuven.

Greco, M., Stenner, P., 2013. Happiness and the art of life: Diagnosing the psychopolitics of wellbeing. Health Cult. Soc. 5, 53-70.

Grossberg, L., 2010. Affect's future: rediscovering the virtual in the actual. In: Gregg, M., Seigworth, G.J. (Eds.), The affect theory reader. Duke University Press, Durham, London.

Hage, G., 2003 [1927]. Against Paranoid Nationalism. Searching for Hope in a Shrinking Society. Pluto Press, Annandale, NSW.

Heidegger, M., 1993. Sein und Zeit. Max Niemeyer, Tuebingen.

Hemmings, C. 2005. Invoking affect: Cultural theory and the ontological turn. Cult. Stud. 19, 548-567.

Isin, E., 2004. The neurotic citizen. Citizsh. Stud. 8, 217-235.

ISTAT, 2011. La popolazione straneira residente in Italia.

Jones, M., Jones, R., Woods, B., 2004. An Introduction to Political Geography: Space, Place and Politics. Routledge, London.
Leach, J., 2006. 'Team spirit'. The pervasive influence of place-generation in 'community building' activities along the Rai Coast of Papua New Guinea. J. Mater. Cult. 11, 87-103.

Macintyre, S., Ellaway, A., Cummins, S., 2002. Place effects on health: How can we conceptualise, operationalise and measure them? Soc. Sci. Med. 55, 125-139.

Massey, D., 1991. The political place of locality studies. Environ. Plan. A 23, 267-281. Massey, D., 1994. Place, Space and Gender. Polity Press, Cambridge.

Massey, D., 1996. Power-geometry and a progressive sense of place. In: Bird, J., Curtis, B., Putnam, T., Robertson, G., Tickner, L. (Eds.), Mapping the Futures: Local Cultures, Global Change. Routledge, London, New York.

Massey, D., 2005. For Space. Sage, London.

Massumi, B., 2002. Parables for the Virtual: Movement, Affect, Sensation. Duke University Press, Durham.

Naisargi, D.N., 2006. Between Queer Ethics and Sexual Morality: Lesbian and Gay Activism in New Delhi, India. Michigan University Press, Ann Arbor.

Pink, S., 2006. The Future of Visual Anthropology: Engaging the Senses. Routledge, Oxford.

Potamianou, A., 1997. Hope: a Shield in the Economy of Borderline States. Routledge, London.

Raffaetà, R., Duff, C., 2013. Putting Belonging into Place: Place Experience and Sense of Belonging among Ecuadorian migrants in an Italian Alpine Region. City \& Society J Anthropol Assoc 25, 328-347.

Rodman, M.C., 1992. Empowering place: multilocality and multivocality. Am Anthropol 94, 640-656.

Seigworth, G.J., Gregg, M., 2010. An inventory of shimmers. In: Gregg, M., Seigworth, G.J (Eds.), The Affect Theory Reader. Duke University Press, Durham, London.

Spinoza, B., 1677. Ethica, ordine geometrico demonstrata.

Thrift, N., 2004. Intensities of feeling: Toward a spatial politics of affect. Geogr. Ann. Ser. B Hum. Geogr. 86 B, 57-78.

Tolia-Kelly, D.P., 2006. Affect - An ethnocentric encounter? Exploring the 'universalist' imperative of emotional/affectual geographies. Area 38.2, 213-217.

Tolia-Kelly, D.P., 2007. Fear in paradise: The affective registers of the English Lake district landscape re-visited. Senses Soc. 2, 329-351.

Wang, C., Burris, M., 1997. Photovoice: Concept, methodology, and use for participatory needs assessment. Health Educ. Behav. 24, 369-387.

Warren, N., Manderson, L., 2008. Constructing hope: Dis/continuity and the narrative construction of recovery in the rehabilitation unit. J. Contemp. Ethnogr. 37, 180-201.

Wise, A., 2005. Hope and belonging in a multicultural suburb. J. Intercult. Stud. 26, 171-186.

Zournazi, M., 2002. Hope: New Philosophies for Change. Pluto Press, Annandale, NSW. 